\title{
Chemical composition and antibacterial effect of Smyrnium olusatrum L. Fruit Essential Oil
}

\author{
Cherif Hamida Saida ${ }^{1}$, Zalegh Imane ${ }^{2, *}$, Saidi Fairouz ${ }^{1}$, Benmanssour Nabahat ${ }^{1}$, M. Carmen González- \\ Mas $^{3}$, M. Amparo Blázquez ${ }^{3}$, Ait Mhand Rajaa ${ }^{2}$ and Akssira Mohamed ${ }^{2}$ \\ ${ }^{1}$ Laboratory of de Biotechnology, Environment and Health, Department of Biology, Faculty of Natural and \\ Life Sciences. University Blida-1, Road from Soumâa, Po Box 270, 09000, Algeria \\ ${ }^{2}$ Laboratory of Physical Chemistry and Bioorganic Chemistry / Research Unit Microbiology, Hygiene \& \\ Biomolecule, Laboratory of Virology, Microbiology, Quality \& Biotechnology / Ecotoxicology and \\ Biodiversity. Faculty of Sciences and Technologies of Mohammedia, University Hassan II Casablanca \\ Morocco, Po box 146- 28800 Mohammedia Morocco \\ ${ }^{3}$ Departament de Farmacologia, Facultat de Farmàcia, Universitat de València, Avd. Vicent Andrés Estellés s/n \\ 46100 Burjassot, Valencia, Spain
}

\begin{abstract}
The plants of the Apiaceae family are mainly used for food purposes and their multiple therapeutic properties and biological activities. This study aims to determine the chemical composition of Essential Oil (EO) of the fruits of Smyrnium olusatrum L. obtained by hydrodistillation in Clevenger-type apparatus. GC/MS analyzed the EO and the antibacterial activity was evaluated against clinical bacterial strains by two complementary methods (Disc diffusion and micro-atmosphere) and determination of Minimal Inhibitory Concentration (MIC). The results of chemical composition show that the EO is dominated by hydrocarbon monoterpenes $(55,95 \%)$. The antibacterial effect shows that Gram-positive bacteria are the most sensitive to the inhibitory action of EO with inhibition zone diameters (DZI) ranging from 18 to $20 \mathrm{~mm}$ for Staphylococcus aureus and Streptococcus faecium strains. The same results were reported with the micro-atmosphere method. Likewise, MIC has been determined for Gram-positive bacteria and show activity at a dilution of 1/100.
\end{abstract}

Keywords: Smyrnium olusatrum; essential oil; chemical composition; antibacterial activity.

\section{Introduction}

The genus Smyrnium L. (Umbelliferae is also known as Apiaceae family) consists of seven species widely distributed throughout the world; they generally prefer temperate regions ${ }^{1}$. Smyrnium olusatrum L., is an umbellifer of this family, commonly known as Alexanders or wild Celery, is a biennial herb, stout, glabrous ${ }^{2}$. Leaves are 2-3-pinnate, dark green, and glossy ${ }^{1}$. It was probably used in prehistory, then became very popular during the time of Alexander the Great (fourth century BC) when it was widely cultivated as a vegetable, and the Romans for its culinary properties also ate it. The latter introduced it into central and Western Europe, including the British Isles, where it is now wholly naturalized.

As a consequence of the changing tastes in the Western world and the introduction and domestication of common celery (Apium graveolens L.) actually, $S$. olusatrum is considered an overlooked horticultural crop ${ }^{3}$.
Several approaches concerned the study of the phytochemical composition of the genus Smyrnium, especially on the olusatrum species roots, stems, leaves, and fruits ${ }^{1,4-8}$. Besides culinary uses, this plant was employed as medicinal during the Greek and Roman ages; the roots were used as antiscorbutic, stomachic and antiasthmatic the juice of the root for its aromatic, appetite stimulant, diuretic and laxative properties, the fruits as and the stems as a depurative antiscorbutic, diuretic, stomachic, laxative ${ }^{6,7,9}$. Many types of research have proved the benefic effects of $S$. olusatrum antileishmanial agent ${ }^{10}$, insecticidal agent ${ }^{11}$. Recently the Isofuranodiene isolated from EO of $S$. olusatrum showed a potential activity as mosquitos larvicidal agent against Culex quinquefasciatus ${ }^{12}$, antifungal agent ${ }^{13-15}$, acaricides agent (neuritogenic activity in vitro) ${ }^{9}$, recently $\mathrm{F}$. Maggiet al and R. Petrelli et al demonstrated respectively that isofuranodiene isolated from $S$. olusatrum have an inhibitor of DHFR (DiHydro Folate Reductase) from 
Escherichia coli, and an inhibitor effect against Trypanosoma bruceiand ${ }^{3,16}$. Also, the Essential Oil (EO) of S. olusatrum has been reported to possess good antiproliferative activity against different cell lines 2,3,17,18, antioxidant activity, and $\alpha$-amylase inhibition ${ }^{1,17}$. One study found that isofuranodiene showed hepatoprotective effects in induced liver injury in rats ${ }^{9}$. On the other hand, some research has focused on the nutritional value of $S$. olusatrum in terms of protein, fibre, fatty acids, and carbohydrates ${ }^{8}$. In Morocco, wild Celery is used by the local population as a condiment and spice ${ }^{19}$, and for traditional medical purposes ${ }^{20}$.

Considering the biological potential for S. olusatrum fruit EO, and to our best knowledge, this is the first Moroccan study aiming the investigation of the chemical composition of the essential oil of fruits of $S$. olusatrum, and in the light of our interest in finding new alternative therapeutic against resistant bacteria that cause serious infectious diseases; the antibacterial activity of our EO was evaluated against clinical strains.

\section{Experimental}

\subsection{Plant material}

The aerial part of Smyrnium olusatrum was collected in the Mohammedia region (Morocco) in April 2011 and was air-dried in the shade at room temperature. The powder of dried fruits was the subject of our work.

\subsection{Extraction of the essential oil}

A $154 \mathrm{~g}$ of dried powder of fruit was extracted by the Clevenger-type apparatus for 3 hours. The oil obtained has a whitish appearance and a characteristic odor of the $S$. olusatrum. The essential oils were weighed and stored at $4^{\circ} \mathrm{C}$ in a sealed brown vial until chemical and biological assays ${ }^{21}$.

\subsection{Chromatographic analysis}

GC/MS analysis was performed on a thermal mass spectrometer (trio1000 model) coupled to thermal gas chromatography (8000 model) (Fisons Instruments) equipped with a non-polar HewlettPackard OV-17 capillary column (25 m long x 0.25 id $\mathrm{mm}$, film thickness $0.25 \mathrm{um}$ ). The temperature program of the column was $60^{\circ} \mathrm{C}$ for $6 \mathrm{~min}$, with an increase of $5^{\circ} \mathrm{C}$ per minute to $150^{\circ} \mathrm{C}$; and maintained for 10 minutes. The carrier gas was helium at a flow rate of $2 \mathrm{ml} / \mathrm{min}$ (splitless mode). The temperature of the detector and injector was maintained at 250 and $225^{\circ} \mathrm{C}$, respectively. The quadruple mass spectrometer was scanned in the range of 28 to 400 amu at an s-1 analysis, with an ionization voltage of $70 \mathrm{eV}$ and an ionization current of $150 \mu \mathrm{A}$. Kovats retention indices (RI) were calculated using coChromatography normalization hydrocarbons. The individual compounds were identified by MS spectra, and their identity was confirmed by comparing their indices for $\mathrm{C} 8-\mathrm{C} 23$ n-alkanes retention and mass spectra with those of authentic samples or with data already available in the NIST library and literature ${ }^{22}$.

\subsection{Antimicrobial activity \\ 2.4.1. Bacteria strains}

The antibacterial activity of essential oil was tested against bacterial strains, including both Grampositive and Gram-negative. All microorganisms tested were isolated from patients admitted in the Infectious Department of the hospital "Boufarik Hospital, Algeria." The isolation and identification of all strains were performed by using physiological and morphological methods. The sensitivity of the essential oil was tested against five clinical Gramnegative bacteria (Proteus mirabilis, Klebsiella pneumonia, Citrobacter freundii, Escherichia coli, and Klebsiella pneumonia producing extendedspectrum $\beta$-lactamase (ESBL)) and two Grampositive bacteria strains Staphylococcus aureus and Streptococcus faecium.

\subsubsection{Inoculum preparation}

All clinical strains were stored at $-20^{\circ} \mathrm{C}$ in Broth BHI/Glycerol. Pure colonies (2-3) were chosen from fresh cultures $(24 \mathrm{~h})$ from an appropriate culture agar (Mac Conkey for Gram-negative strains, Chapman for S. aureus, and Mueller-Hinton for S. feacium). A first suspension was prepared in sterile distilled water, having 0.5 McFarland turbidity (the suspensions contained $10^{8} \mathrm{CFU} / \mathrm{mL}$ of bacteria). For the test, a dilution of $1 / 100$ was used for final inoculum concentrations of $10^{6} \mathrm{CFU} / \mathrm{mL}$ bacteria.

The antibacterial properties of the EO were studied using two techniques: Disc-diffusion agar and Micro-atmosphere method for determining the zone of inhibition, and microdilution assay for determining the Minimum Inhibitory Concentration (MIC).

\subsubsection{Micro-atmosphere method}

We performed this test in order to evaluate the antibacterial activity of the volatile oil against both Gram-positive and Gram-negative bacteria. The bacterial inoculum was inoculated to the surface of Mueller-Hinton medium agar with sterile cotton swabs. $2.5 \mu \mathrm{L}$ of EO was placed on a filter paper disc in the center of the cover of the Petri dish, which is incubated with an inverted lid ${ }^{23}$. The dishes were rapidly sealed with parafilm to avoid the evaporation of the EO. The presence or absence of the growth was noted after incubation of the bacteria at $37^{\circ} \mathrm{C}$ for $24 \mathrm{~h}$.

\subsubsection{Disc-diffusion assay}

The antibacterial activity of the essential oil was first determined by a diffusion method according to the Clinical and Laboratory Standards Institute (CLSI) for bacteria and yeasts testing ${ }^{24}$. $1 \mathrm{~mL}$ of each bacterial inoculum was inoculated to the surface of Mueller-Hinton medium agar with sterile cotton 
swabs. The sterile discs (6 $\mathrm{mm}$ diameter) were impregnated with $2.5 \mu \mathrm{L}$ of $S$. olusatrum EO. Then all discs were left on medium for complete diffusion of the EO. Before incubating Petri dishes at $37^{\circ} \mathrm{C}$, they were left for 1 hour at room temperature. Amoxicillin (25 $\mu \mathrm{g} / \mathrm{disk}), \quad$ Amoxicillin+acid clavulanic (20/10 $\mu \mathrm{g} /$ disk), Cefoxitin $(30 \mu \mathrm{g} / \mathrm{disk})$, Cefotaxime (30 $\mu \mathrm{g} / \mathrm{disk})$, Cefalexin $(30 \mu \mathrm{g} / \mathrm{disk})$ and Trimethoprim-Sulfamethoxazole(1.25-23.75 $\mu \mathrm{g} / \mathrm{disk})$ served as positive reference standards to determine the sensitivity of bacterial strains tested and to compare the inhibitory action of the EO with positive controls. All these antibiotics were tested on the surface of Mueller-Hinton medium inoculated with bacterial strains in the same conditions of EO. All inoculated plates were incubated at $37^{\circ} \mathrm{C}$ for $24 \mathrm{~h}$. Antimicrobial activity was evaluated by measuring the zone of inhibition against the tested organisms.

\subsubsection{Determination of the minimum inhibitory concentration (MIC)}

The antibacterial activity of the EO was also evaluated by a microdilution method by determining the minimum inhibitory concentration (MIC). The MIC was measured only for Gram-positive bacteria (Staphylococcus aureus and Streptococcus faecium). The inoculate were prepared in broth cultures, and suspensions were adjusted to $0.5 \mathrm{McF}$ arland standard turbidity. MICs were determined according to Demetzos et al. (1995), with slight modifications ${ }^{20}$. $1 \mathrm{~mL}$ of EO was first diluted with $9 \mathrm{~mL}$ of solution A which contain $(2.5 \mathrm{~mL}$ of Tween $80+90 \mathrm{~mL}$ of distilled $\mathrm{H}_{2} \mathrm{O}$ ), and then serial of three-fold were made between 1/10, 1/100 and 1/1000. Bacterial inoculum was prepared from fresh colonies in Mueller-Hinton Broth medium, and 13.5 $\mu \mathrm{L}$ were added to each test tube as well as the control tube, and then $1.5 \mathrm{~mL}$ of each solution was added. All tubes were incubated at $37^{\circ} \mathrm{C}$ with agitation for 24 hours. After incubation, the tubes were centrifuged at $5000 \mathrm{~g}$ for 5 minutes at $20^{\circ} \mathrm{C}$.

The MIC of the tested EO was established as the lowest sample concentration to prevent visible growth.

The three methods used for the determination of the antibacterial activity of the essential oil were performed in triplicate in three different experiments.

\section{Results and Discussion}

\subsection{Composition of the EO of wild Celery}

A total of 32 different compounds accounting for $84.03 \%$ of $S$. olusatrum essential oil, were identified by GC/MS analysis. Components are clustered (Table 1) in homologous series of monoterpene hydrocarbons, oxygenated monoterpenes, sesquiterpene hydrocarbons, oxygenated sesquiterpenes, and aromatic compounds and listed according to Kovat's retention index calculated in GC on apolar HP-5MS column. Monoterpene hydrocarbons $(55.95 \%)$ with 10 identified compounds were the main phytochemical group found in the essential oil obtained from the fruits of $S$. olusatrum collected in Mohammedia region (Morocco.) $\beta$-Pinene (24.96\%), followed by $\beta$-phellandrene $(21.85 \%), \alpha$-pinene $(5.43 \%)$ and myrcene $(2.67 \%)$ were the principal components of this fraction. The other monoterpene hydrocarbons were found in percentages lower than $1 \%$. Similar content of monoterpene hydrocarbons was found in the essential oils from green and ripe fruits of $S$. olusatrum harvested from Lewes (England) but with quantitative differences between the main compounds. $\beta$-phellandrene was the principal component of the essential oil from the green $(33.20 \%)$ and ripe fruits $(26.94 \%)$ followed by high amounts of $\alpha$-pinene (8.61 and $12.45 \%$, respectively) instead of $\beta$-pinene, which only reached percentages of $1.46 \%$ and $4.18 \%$, in green and ripe fruits, respectively ${ }^{4}$. Oxygenated sesquiterpenes were the next quantitative phytochemical group in the essential oil here analyzed. Germacrone $(8.41 \%)$ and the furane derivative curzerene $(8.21 \%)$ were the leading identified compounds of this fraction, Germacrone was previously found in different species of the genus Smyrnium, such as S. olusatrum, $S$. creticum and, so it can be considered as a chemotaxonomic marker ${ }^{8}$. Curzerene (27.3\%, $25.0 \%$, and $21.3 \%$ ) was the main compound of the essential oils from the ripe fruits of $S$. olusatrum collected in three localities of the Appennino UmbroMarchigiano (Italy), followed by $\alpha$-pinene $(16.8 \%, 16.0 \%$, and $12.0 \%)$ and $\beta$-phellandrene $(15.0 \%, 6.1 \%$, and $8.3 \%)$. Again $\beta$-pinene, the main compound in the essential oil here analyzed reached less $(2.5 \%, 4.3 \%$, and $7.1 \%)$ percentages ${ }^{5}$. Among the oxygenated sesquiterpenes in the essential oil here analyzed, a large amount $(1.20 \%, 1.26 \%$, and $9.97 \%$ ) of unidentified furanosesquiterpenoids was found. The content of furanosesquiterpenoids was higher by supercritical $\mathrm{CO}_{2}$ extraction than by hydrodistillation process in wild $S$. olusatrum samples from Portugal and Italy ${ }^{14}$. Hydrodistillation in a Clevenger-type apparatus for $6 \mathrm{~h}$ resulted in a high content of the furanosesquiterpenoids isofuranodiene $(24.6 \%$ and $26.7 \%)$, $1 \beta$-acetoxyfuranoeusdesm- $4(15)$-ene $\quad(31.0 \%$ and $16.5 \%)$ and curzerene $(5.0 \%$ and $6.6 \%)$ in green and ripe fruits samples collected in San Giusto (Italy) ${ }^{6}$. $1 \beta$-Acetoxyfuranoeusdesm-4(15)-ene was also the main compound in the essential oils of $S$. olusatrum collected in 18 localities to five different regions (Marche, Umbria, Abruzzo, Tuscany and Latium) of Italy ${ }^{8}$ as well as in ripe fruits collected in Greece (1 $\beta$-acetoxyfuranoeusdesm-4(15)-ene, 30.8\%). 
Table 1. Chemical composition of EO of Smyrnium olusatrum L. fruits.

\begin{tabular}{|c|c|c|}
\hline $\mathbf{R I}$ & Compound & $\begin{array}{c}\text { S. olusatrum } \\
\text { Peak area (\%) }\end{array}$ \\
\hline \multicolumn{2}{|c|}{ Monoterpene hydrocarbons } & 55.95 \\
\hline 931 & $\alpha$-Thujene & 0.15 \\
\hline 939 & $\alpha$-Pinene & 5.43 \\
\hline 953 & Camphene & 0.05 \\
\hline 979 & $\beta$-Pinene & 24.96 \\
\hline 993 & Myrcene & 2.67 \\
\hline 1005 & $\alpha$-Phellandrene & 0.60 \\
\hline 1012 & $\delta$-3-Carene & 0.06 \\
\hline 1031 & $\beta$-Phellandrene & 21.85 \\
\hline 1053 & trans- $\beta$-Ocimene & 0.10 \\
\hline 1090 & Terpinolene & 0.08 \\
\hline \multicolumn{2}{|c|}{ Oxygenated monoterpenes } & 2.46 \\
\hline 1101 & Linalool & 0.19 \\
\hline 1123 & trans-p-Mentha-2,8-dien-1-ol & 0.15 \\
\hline 1139 & trans-Pinocarveol & 0.05 \\
\hline 1140 & trans-p-Mentha-2-en-1-ol & 0.17 \\
\hline 1165 & Pinocarvone & 0.05 \\
\hline 1179 & Terpinen-4-ol & 0.15 \\
\hline 1184 & Cryptone & 0.50 \\
\hline 1190 & $\alpha$-Terpineol & 0.81 \\
\hline 1208 & trans-Piperitol & 0.05 \\
\hline 1242 & Cumin aldehyde & 0.05 \\
\hline 1381 & Geranyl acetate & 0.29 \\
\hline \multicolumn{2}{|c|}{ Sesquiterpene hydrocarbons } & 8.12 \\
\hline 1390 & $\beta$-Elemene & 1.65 \\
\hline 1437 & $\gamma$-Elemene & 1.11 \\
\hline 1454 & $\alpha$-Humulene & 0.08 \\
\hline 1485 & Germacrene D & 0.55 \\
\hline 1509 & $\beta$-Bisabolene & 0.47 \\
\hline 1524 & $\delta$-Cadinene & 0.26 \\
\hline 1561 & Germacrene B & 4.00 \\
\hline \multicolumn{2}{|c|}{ Oxygenated sesquiterpenes } & 17.38 \\
\hline 1500 & Curzerene & 8.21 \\
\hline 1590 & cis- $\beta$-Elemenone & 0.76 \\
\hline 1695 & Germacrone & 8.41 \\
\hline \multicolumn{2}{|c|}{ Aromatic compounds } & 0.12 \\
\hline \multirow[t]{2}{*}{1258} & 2-Penylethyl acetate & 0.12 \\
\hline & Total & 84.03 \\
\hline
\end{tabular}

RI, retention index relative to $\mathrm{C}_{8}-\mathrm{C}_{32} n$-alkane on HP-5MS column. 
However, in unripe infructescence, curzerene with a percentage of $29.7 \%$ was the main furanosesquiterpenoid ${ }^{25}$. Germacrone, the main oxygenated sesquiterpene in the essential oil here analyzed, was found to be one of the main constituents in the inflorescences from both Italy $(5.2-41.5 \%)^{8}$ and Greece (curzerene $38.1 \%$ and germacrone $20.2 \%)^{25}$.

Comparing our data with previous studies, the EO composition of the fruits of S. olusaltrum showed an obvious similarity, characterized by a predominance of monoterpenes, with slight quantitative differences in marker compounds. Indeed, although all these countries are different, they all belong to the Mediterranean region. Moreover, the published data relating to the chemotype of aromatic plants support the influence of genotypes as well as ecotypes (light, precipitation, growing site, and nature of the soil ( $\mathrm{pH}$, constituents) seasonal variation), but also the age and part of plant ${ }^{26-29}$.

\subsection{Antibacterial activity}

The micro-atmosphere test is based on the action of volatile compounds, which can significantly inhibit the growth of some bacteria. Few studies have analyzed the effect of the volatile phase of EO on the growth of microbial strains; however, the role of essential oils in the vapor phase as antimicrobial agents is gaining increasing significance ${ }^{30}$. The results of the antibacterial activity of the essential oil of $S$. olusatrum L. are recorded in Table 2 and shows that all Gram-negative bacteria continued to multiply, showing resistance to $S$. olusatrum EO, but Gram-positive were completely inhibited. The volatile phase of EO is, therefore, more active against Gram-positive strains. This is consistent with the work of Quassinti et al., which reported that essential oil extracted from Italian S. olusatrum was not active on Gram-negative, especially $P$. aeruginosa and E. coli (diameter $=6 \mathrm{~mm}$ ) ${ }^{6}$. Also, most previous studies on essential oils have shown that Gram-positive bacteria are generally the most sensitive to the vapor phase inhibitory action of terpenoid molecules ${ }^{31}$. However, some exceptions have been reported in the literature, indicating that there is no apparent link or positive correlation between the nature of the bacterial wall and the degree of inhibition of the microbial strains ${ }^{32}$. The results we have obtained in the micro-atmosphere, particularly against $S$. aureus and $S$. faecium suggest the possibility of using this volatile phase of EO as an atmospheric disinfectant in the pharmaceutical or food industries or against airborne contamination in hospitals.

This result is related firstly to the nature of some volatile substances contained in EO that inhibit the growth of the most bacteria during the period of incubation. In point of fact, according to Belletti et al. (2004), the antibacterial power of EO is attributed to its various components such as terpenes, alcohols, aldehydes, and esters ${ }^{33}$. On the other hand, the nature of the bacterial cell wall is directly related to the result.

Table 2. Evaluation of the antibacterial activity of EO of S. olusatrum, by micro-atmosphere and disc diffusion.

\begin{tabular}{|c|c|c|c|c|c|c|c|c|}
\hline \multirow{3}{*}{ Microorganism } & \multicolumn{8}{|c|}{ Diameter of Zone Inhibition (mm) } \\
\hline & \multirow[t]{2}{*}{ MA } & \multirow[t]{2}{*}{ DD } & \multicolumn{6}{|c|}{ Controls positive (antibiotics discs) } \\
\hline & & & $\mathrm{AMC}$ & $\mathrm{AM}$ & $\mathrm{CN}$ & FOX & CTX & SXT \\
\hline \multicolumn{9}{|l|}{ Gram-negative bacteria } \\
\hline Proteus mirabilis & + & 9 & 20 & 24 & 12 & 18 & 20 & 10 \\
\hline Klebsiella pneumonia & + & 9 & 20 & 07 & 12 & 10 & 20 & 20 \\
\hline $\begin{array}{l}\text { Klebsiella pneumonia } \\
\text { (ESBL) }\end{array}$ & + & 8.5 & 11 & 07 & 15 & 17 & 10 & 10 \\
\hline E. coli $(\mathrm{ESBL})$ & + & 9 & 11 & 07 & 22 & 24 & 10 & 22 \\
\hline Citrobacter freundii & + & 8 & 20 & 06 & 22 & 24 & 20 & 22 \\
\hline \multicolumn{9}{|l|}{ Gram-positive bacteria } \\
\hline Staphylococcus aureus & - & 18 & & & & 07 & 08 & \\
\hline Streptococcus faecium & - & 20 & & & & & 07 & \\
\hline \multicolumn{9}{|c|}{$\begin{array}{l}\text { MA: Micro-atmosphere }(2.5 \mu \mathrm{L}) \text {; DD: Dsic-diffusion }(2.5 \mu \mathrm{L}) ;(+) \text { : Bacterial growth; (-): Inhibition; ESBL: } \\
\text { Extended-Spectrum } \beta \text {-Lactamase; AM: Amoxicillin }(25 \mu \mathrm{g}) \text {; AMC: Amoxicillin/acid clavulanic }(20 / 10 \mu \mathrm{g}) \text {; } \\
\text { FOX: Cefoxitin }(30 \mu \mathrm{g}) \text {; CTX: Cefotaxime }(30 \mu \mathrm{g}) \text {; SXT: Trimethoprim/Sulfamethoxazol }(1.25 / 23.75 \mu \mathrm{g}) \text {; CN: } \\
\text { Cefalexin }(30 \mu \mathrm{g}) \text {. Diameter of disc }(6 \mathrm{~mm}) \text {. }\end{array}$} \\
\hline
\end{tabular}

Table 2 lists the diameters of the inhibition zones around the discs containing the EO extracted from fruits. As regards to the spectrum of action, it should be noted that the essential oil of S. olusatrum L. has a weak action against Gram-negative strains (DZI between $8.5 \mathrm{~mm}$ and $9 \mathrm{~mm}$ ), but has an intense effect 
against Gram-positive bacteria, with inhibition halos between $18 \mathrm{~mm}$ for $S$. aureus, and $20 \mathrm{~mm}$ for $S$. faecium. These results are consistent with the previous study, which correlated the activity of EO to bacterial cell wall ${ }^{31-33}$. Gram-negative bacteria have a two-membrane cell wall encompassing a periplasmic space that contains enzymes, which are capable of degrading terpenoid molecules and, therefore, avoiding their entry into the cell. Contrary to Gram-positive bacteria, which have a single layer wall, so are more rapidly inhibited.

The comparison of the activity of EO and the positive controls showed that some antibiotics such AM or FOX and CTX are less effective against some strains tested than the EO. This is an exciting finding, especially the good activity of the EO against $S$. aureus and $S$. feacium, which are involved in a large number of nosocomial infections. It's important to underline that these two strains are characterized by severe virulence and a severe problem of resistance to the main antibiotics. Another consideration is their capacity, especially $S$. aureus, to survive for a long time in the Hospital environment by forming biofilms (Table 2).

The determination of MIC was only used for species that have shown a high sensitivity to EO by disc- diffusion method and micro-atmosphere assay. Four different concentrations of EO were tested (Table 3). Our data clearly indicate that the three first concentrations (stock solution $(10.000 \mu \mathrm{g} / \mathrm{mL}$ ), 1000 $\mu \mathrm{g} / \mathrm{mL}, 100 \mu \mathrm{g} / \mathrm{mL}$ inhibit the growth of both Grampositive bacteria tested. In contrast, the $10 \mu \mathrm{g} / \mathrm{mL}$ dilution does not affect any of them.

Therefore, the MICs for both Gram-positive strains are in the order of $10 \mu \mathrm{g} / \mathrm{mL}$. Overall, our results concerning the excellent activity of the EO against Gram-positive bacteria, determined by the three methods used, correlate well with literature data ${ }^{13-15,34,35}$.

We also find, as reported by the previous study, that the antimicrobial activity of the Eos, tested by determining MIC, is due to the predominance of monoterpene hydrocarbons in their chemical composition ${ }^{36-38}$. These later represent $55,95 \%$ with $\beta$-Pinene founded in great amount $(24.96 \%)$; they are responsible for the increase in the membrane fluidity, causing the outflow of intracellular components followed by the death of microorganisms. It also possible that minority compounds act synergistically. The value of essential oil, therefore, depends on all its components, and not only on the majority of compounds ${ }^{31}$.

Table 3. Minimal inhibitory concentration (MIC) of EO from S. olusatrum against two microorganisms.

\begin{tabular}{|c|c|c|c|c|}
\hline Strains & $\begin{array}{c}\text { Stock solution } \\
\mathbf{1 0 . 0 0 0 u g} / \mathbf{m L}\end{array}$ & $\begin{array}{c}\text { Dilution } 1 / 10 \\
\mathbf{1 0 0 0 u g} / \mathbf{m L}\end{array}$ & $\begin{array}{c}\text { Dilution } 1 / 100 \\
\mathbf{1 0 0} \mathbf{~ u g} / \mathbf{m L}\end{array}$ & $\begin{array}{c}\text { Dilution } 1 / 1000 \\
\mathbf{1 0 u g} / \mathbf{m L}\end{array}$ \\
\hline Staphylococcus aureus & - & - & - & + \\
\hline Streptococcus faecium & - & - & - & + \\
\hline
\end{tabular}

(-): Absence of growth; (+): Presence of growth; MIC: Minimum Inhibitory Concentration

\section{Conclusion}

Our work contributes to a reconsideration of the species S. olusatrum L., especially for her activity against two Gram-positive $S$. aureus and $S$. faecium, the pathogens that cause serious infections and have a remarkable ability to acquire resistance to a wide range of antibiotics complicating treatment of these infections.

Our results are integrated with all the research aimed at promoting and valorization of this neglected species, and shed light on the possible application of its essential oil not only as an atmospheric disinfectant for pharmaceutical and food industries but also as a natural alternative therapy. Further studies need to be performed for identifying bioactive molecules.

\section{Acknowledgements}

The authors are thankful to the members of Facultat de Farmàcia, Universitat de València, for the GCMS measurements.

\section{References}

1- C. Messaoud, B. Amina, M. Boussaid, Phytochemicals, antioxidant and-amylase inhibitory activities of Smyrnium olusatrum L. Leaf, flower and fruit, Scientific Bulletin Series F Biotechnologies, 2013, 17, 212-220.

2- A. Brunetti, O. Marinelli, M. B. Morelli, R. Iannarelli, C. Amantini, D. Russotti, G. Santoni, F. Maggi, M. Nabissi, Isofuranodiene synergizes with temozolomide in inducing glioma cells death, Phytomedicine, 2019, 52, 51-59.

3- F. Maggi, F. Papa, S. Pucciarelli, M. Bramucci, L. Quassinti, L. Barboni, D. D. Ben, A. T. Ramadori, C. Graiff, R. Galassi, Stabilization of the cyclodecadiene derivative isofuranodiene by silver (I) coordination. Mechanistic and biological aspects, Fitoterapia, 2017, 117, 52-60.

4- U. Molleken, S. Volker, K. Karl-Heinz, The Essential Oil composition of fruits from Smyrnium perfoliatum, Phytochemistry, 1998, 47, 1079-1083. 
5- F. Maggi, L. Barboni, F. Papa, G. Caprioli, M. Ricciutelli, G. Sagratini, S. Vittori, A forgotten vegetable (Smyrnium olusatrum L., Apiaceae) as a rich source of isofuranodiene, Food Chemistry, 2012, 135, 2852-2862.

6- L. Quassinti, M. Bramucci, G. Lupidi, L. Barboni, M. Ricciutelli, G. Sagratini, F. Papa, G. Caprioli, D. Petrelli, L. A. Vitali, S. Vittori, F. Maggi, In vitro biological activity of essential oils and isolated furanosesquiterpenes from the neglected vegetable Smyrnium olusatrum L. (Apiaceae), Food Chemistry, 2013, 138, 808-813.

7- L. Quassinti, F. Maggi, L. Barboni, M. Ricciutelli, M. Cortese, F. Papa, C. Garulli, C. Kalogris, S. Vittori, M. Bramucci, Wild celery (Smyrnium olusatrum L.) oil and isofuranodiene induce apoptosis in human colon carcinoma cells, Fitoterapia, 2014, 97, 133-141.

8- F. Maggi, F. Papa, C. Giuliani, L. Maleci Bini, A. Venditti, A. Bianco, M. Nicoletti, R. Iannarelli, G. Caprioli, G. Sagratini, M. Cortese, M. Ricciutelli, S. Vittori, Essential oil chemotypification and secretory structures of the neglected vegetable Smyrnium olusatrum L. (Apiaceae) growing in central Italy: Phytochemical investigation of Smyrnium olusatrum, Flavour and Fragrance Journal, 2015, 30, 139-159.

9- W. Li, J. Shi, F. Papa, F. Maggi, X. Chen, Isofuranodiene, the main volatile constituent of wild celery ( Smyrnium olusatrum L.), protects Dgalactosamin/lipopolysacchride-induced liver injury in rats, Natural Product Research, 2016, 30, 1162-1165.

10-J. El-On, L. Ozer, J. Gopas, R. Sneir, H. Enav, N. Luft, G. Davidov, A. Golan-Goldhirsh, Antileishmanial activity in Israeli plants, Annals of Tropical Medicine \& Parasitology, 2009, 103, 297-306.

11-G. Benelli, R. Pavela, R. Iannarelli, R. Petrelli, L. Cappellacci, K. Cianfaglione, F. H. Afshar, M. Nicoletti, A. Canale, F. Maggi, Synergized mixtures of Apiaceae essential oils and related plant-borne compounds: Larvicidal effectiveness on the filariasis vector Culex quinquefasciatus Say, Industrial Crops and Products, 2017, 96, 186-195.

12-R. Pavela, L. Pavoni, G. Bonacucina, M. Cespi, N. G. Kavallieratos, L. Cappellacci, R. Petrelli, F. Maggi, G. Benelli, Rationale for developing novel mosquito larvicides based on isofuranodiene microemulsions, J Pest Sci., 2019, 92, 909-921.

13-H. Daroui-Mokaddem, A. Kabouche,

M. Bouacha, B. Soumati, A. El-Azzouny, C. Bruneau, Z. Kabouche, GC/MS Analysis and Antimicrobial Activity of the Essential Oil of Fresh Leaves of Eucalytus Globulus, and Leaves and Stems of Smyrnium Olusatrum from Constantine (Algeria), Natural Product Communications, 2010, 5, 1934578X1000501.
14-B. Marongiu, A. Piras, S. Porcedda, D. Falconieri, M. A. Frau, A. Maxia, M. J. Gonçalves, C. Cavaleiro, L. Salgueiro, Antifungal activity and chemical composition of essential oils from Smyrnium olusatrum L. (Apiaceae) from Italy and Portugal, Natural Product Research, 2012, 26, 993-1003.

15-G. Tsasi, M. Soković, A. Cirić, E. Eriotou, E. Sakadani, Y. Samaras, H. Skaltsa, Antifungal Compounds Isolated from Smyrnium olusatrum L. Essential Oil, Growing Wild in Cephalonia, Greece. Chemical Analysis and Structure Elucidation, Rec Nat Prod., 2016, 10, 93.

16-R. Petrelli, F. Ranjbarian, S. Dall'Acqua, F. Papa, R. Iannarelli, S. L. Ngahang Kamte, S. Vittori, G. Benelli, F. Maggi, A. Hofer, L. Cappellacci, An overlooked horticultural crop, Smyrnium olusatrum, as a potential source of compounds effective against African trypanosomiasis, Parasitology International, 2017, 66, 146-151.

17-M. Marrelli, B. Cristaldi, F. Menichini, F. Conforti, Inhibitory effects of wild dietary plants on lipid peroxidation and the proliferation of human cancer cells, Food and Chemical Toxicology, 2015, 86, 16-24.

18-M. Cespi, L. Quassinti, D. R. Perinelli, M. Bramucci, R. Iannarelli, F. Papa, M. Ricciutelli, G. Bonacucina, G. F. Palmieri, F. Maggi, Microemulsions enhance the shelf-life and processability of Smyrnium olusatrum L. essential oil: Microemulsions enhance shelf-life and processability of AEO, Flavour and Fragrance Journal, 2017, 32, 159-164.

19-J. Bellakhdar, LA Pharmacopée Marocaine traditionnelle médecine arabe ancienne et savoirs populaires, Éditions Le Fennec, Ibis Press: Paris, 1997.

20-C. Demetzos, A. Loukis, V. Spiliotis, N. Zoakis, N. Stratigakis, H. E. Katerinopoulos, Composition and Antimicrobial Activity of the Essential oil of Cistus creticus L., Journal of Essential Oil Research, 1995, 7, 407-410.

21-A. Asdadi, H. Alilou, M. Akssira, L. M. I. Hassani, B. Chebli, R. Moutaj, C. Gonz, I. Zohr, Chemical Composition and Anticandidal Effect of Three Thymus Species Essential Oils from Southwest of Morocco against the Emerging Nosocomial Fluconazole-Resistant Strains, Journal of Biology, Agriculture and Healthcare, 2014, 4, 16-26.

22-R. P. Adams, Identification of essential oil components by gas chromatography/mass spectrometry, Allured publishing corporation Carol Stream, IL, 2007, 456.

23-P. Kloucek, J. Smid, A. Frankova, L. Kokoska, I. Valterova, R. Pavela, Fast screening method for assessment of antimicrobial activity of essential oils in the vapor phase, Food Research International, 2012, 47, 161-165.

24-J. B. Patel, Clinical and Laboratory Standards Institute Eds., Performance standards for 
antimicrobial disk susceptibility test; approved standards, 12. ed. Committee for Clinical Laboratory Standards: Wayne, PA, 2015.

25-H. J. D. Dorman, S. G. Deans, Antimicrobial agents from plants: antibacterial activity of volatile plant oils, Journal of Applied Microbiology, 2000, 88, 308-316.

26-X. He, S. Wang, J. Shi, Z. Sun, Z. Lei, Z. Yin, Z. Qian, H. Tang, H. Xie, Genotypic and Environmental Effects on the Volatile Chemotype of Valeriana jatamansi Jones, Front Plant Sci., 2018, 9, 1003.

27-G. Flamini, P. L. Cioni, I. Morelli, M. Macchia, L. Ceccarini, Main Agronomic-Productive Characteristics of Two Ecotypes of Rosmarinus officinalis L. and Chemical Composition of Their Essential Oils, J Agric Food Chem., 2002, 50, 3512-3517.

28-T. da Silva de Souza, M. F. da Silva Ferreira, L. Menini, J. R. C. de Lima Souza, L. A. Parreira, P. R. Cecon, A. Ferreira, Essential oil of Psidium guajava: Influence of genotypes and environment, Scientia Horticulturae, 2017, 216, 38-44.

29-S. E. Zytynska, Y. Guenay, S. Sturm, M. V. Clancy, M. Senft, J. Schnitzler, S. Dilip Pophaly, C. Wurmser, W. W. Weisser, Effect of plant chemical variation and mutualistic ants on the local population genetic structure of an aphid herbivore, J Anim Ecol., 2019, 88, 1089-1099.

30-H. Fasihi, N. Noshirvani, M. Hashemi, M. Fazilati, H. Salavati, V. Coma, Antioxidant and antimicrobial properties of carbohydratebased films enriched with cinnamon essential oil by Pickering emulsion method, Food Packaging and Shelf Life, 2019, 19, 147-154.

31-N. Belletti, M. Ndagijimana, C. Sisto, M. E. Guerzoni, R. Lanciotti, F. Gardini, Evaluation of the Antimicrobial Activity of Citrus Essences on Saccharomyces cerevisiae, Journal of Agricultural and Food Chemistry, 2004, 52, 6932-6938.
32-M. S. Ali-Shtayeh, R. M.-R. Yaghmour, Y. R. Faidi, K. Salem, M. A. Al-Nuri, Antimicrobial activity of 20 plants used in folkloric medicine in the Palestinian area, Journal of Ethnopharmacology, 1998, 60, 265-271.

33-J. A. H. Rmaniuk, L. Cegelski, Bacterial cell wall composition and the influence of antibiotics by cell-wall and whole-cell NMR, Philosophical Transactions of the Royal Society B: Biological Sciences, 2015, 370, 20150024.

34-H. Amiri, R. A. Khavari-Nejad, S. Masoud, F. Chalabian, A. Rustaiyan, Composition and Antimicrobial Activity of the Essential Oil from Stems, Leaves, Fruits, and Roots of Smyrnium cordifolium Boiss, Journal of Essential Oil Research, 2006, 18, 574-577.

35-M. Khanahmadi, S. H. Rezazadeh, M. Taran, In vitro Antimicrobial and Antioxidant Properties of Smyrnium cordifolium Boiss. (Umbelliferae) Extract, Asian Journal of Plant Sciences, 2010, 9, 99-103.

36-A. Takikawa, K. Abe, M. Yamamoto, S. Ishimaru, M. Yasui, Y. Okubo, K. Yokoigawa, Antimicrobial Activity of Nutmeg against Escherichia coli O157, Journal of Bioscience and Bioengineering, 2002, 94, 315-320.

37-A. Rosato, F. Maggi, K. Cianfaglione, F. Conti, G. Ciaschetti, R. Rakotosaona, G. Fracchiolla, M. L. Clodoveo, C. Franchini, F. Corbo, Chemical composition and antibacterial activity of seven uncommon essential oils, Journal of Essential Oil Research, 2018, 30, 233-243.

38-C. M. D. Sylvie, T. Jean-De-Dieu, S. S. N. Guy, T. Pierre, K. Jules-Roger, Chemical composition and antimicrobial activity of essential oils from Aframomum citratum, Aframomum daniellii, Piper capense and Monodora myristica, J Med Plants Res., ., 2019, 13, 173-18. 